\title{
Sobre guerra, medios populares y responsabilidades de la vanguardia: folletines, caricaturas, guías turísticas y manifiestos
}

\author{
About war, popular media \\ and responsabilities of the avant-garde: \\ leaflets, caricatures, \\ guidebooks and manifests
}

\author{
JUAN JOSÉ LAHUERTA \\ Escola Tècnica Superior d'Architectura de Barcelona (España)
}

Recibido: 1-X-2015 Aceptado: 22-X-2015

\begin{abstract}
RESUMEN
Durante la Primera Guerra Mundial y en los años anteriores y posteriores una gran cantidad de arte y literatura se dedica a la exaltación del conflicto, a su justificación, a su lamento. Esta literatura y este arte discurren por todos los estratos de la sociedad: desde folletines sentimentales, cuentos e historietas de guerra, relatos bélicos de gran consumo o guías turísticas de los campos de batalla, hasta novelas y poemas de grandes autores; desde caricatura popular hasta obras de artistas reputados. Todo ello tiene un denominador común: el terrible empobrecimiento del lenguaje, por un lado, y, por otro, la convicción por parte de algunas élites intelectuales de que, en cualquier caso, ya no hay nada que decir. En el mundo del nihilismo imperfecto que se deriva de todo ello aparece un gran responsable: la vanguardia, que ve en la guerra la realización de algunas de sus fantasías, todas ellas relacionadas con la voluntad de destrucción.
\end{abstract}




\section{PALABRAS CLAVE \\ GUERRA, VANGUARDIA, FUTURISMO, MARINETTI, CARICATURA}

\section{ABSTRACT}

During World War, and in the years before and after, a large number of art and literature is dedicated to the exaltation of conflict, its justification, its lament. This literature and this art is therefore in all strata of society: from sentimental series, tales and comic books, war stories of grand consumption or guidebooks of the battle field, to novels and poems of great authors; from popular cartoons to works by renowned artists. All have a common denominator: the terrible impoverishment of language, on the one hand, and the other, the conviction by some intellectual elites that there is nothing to say, in any case. In the world of imperfect nihilism that results from all this appears a great responsible factor: the avant-garde, that sees in war the performing of some of its fantasies, all related to the will of destruction.

\section{KEYWORDS}

WAR, AVANT, GARDE, FUTURISM, MARINETTI, CARTOON

DE ENTRE LOS MUCHÍSIMOS LIBROS DE GUERRA que se publicaron en los años 1914-1918, libros de propaganda, dirigidos, libros y poemas heroicos y ridículos, ridículos por heroicos tanto como heroicos por ridículos, libros surgidos de tantas «plumas bañadas en sangre», como decía Karl Kraus, que dejando como dejaron sus alegatos entre tanta información y tanto teatro teatro de guerra, teatro de operaciones...- acabaron por herir de muerte al lenguaje provocando su «catástrofe», de entre tanta voz de periodismo y tanto anuncio al que el azote de los «últimos días de la humanidad» no daba abasto, de entre esos miles de libros, digo, escojamos uno, simplemente, sin intención, por casualidad, un pequeño libro que lleva por título La Guerre, Madame...

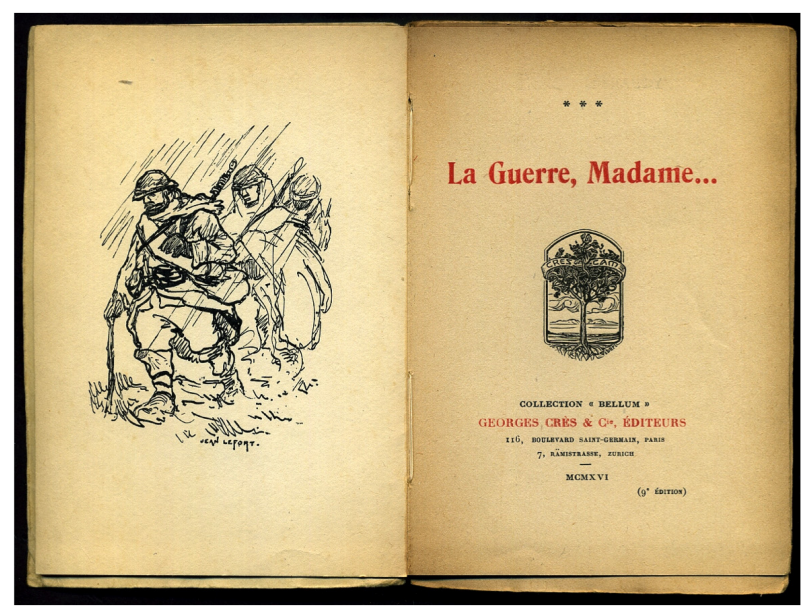

Fig. 1 
Publicado en 1916, por Crès \& Cie., en una colección apropiadamente titulada «Bellum», se ilustraba con un frontispicio de Jean Lefort (Géraldy 1916) [fig. 1], ya en ese momento reconocido autor de dibujos y grabados de guerra -o impresiones, como con toda propiedad se decía entonces. Ahí están, en efecto, en esa ilustración, bajo la lluvia, en medio del barro, con sus capotes y sus cascos y todo su utillaje, los soldados: impresión de lluvia, impresión de guerra... sketch!

La Guerre, Madame... apareció anónimamente, sin duda para hacer más verosímil su historia, sobre todo teniendo en cuenta el golpe de efecto final: en realidad el protagonista, el narrador, está muerto, y las últimas líneas del libro no son más que la transcripción «fría y objetiva» del parte de su muerte, muerte heroica, cómo no, a pesar del lenguaje oficial -o gracias a él, si seguimos la lógica del contraste que todos esos librillos proponen entre la necesaria frialdad del ejército-patria-fábrica y la presencia-ausencia del soldado desconocido, versión última y concluyente, definitivamente terrible y banal, de aquellos héroes de la vida moderna que soportan sobre sus hombros ya no el peso de la historia sino el de lo cotidiano, siendo lo cotidiano la miseria, la guerra y la muerte: «Maurice Vernier... gravemente herido en el momento en que armado con una bomba conducía a sus soldados al asalto de una trinchera enemiga, ha sucumbido a sus heridas», etc. etc.

Pero ese anonimato era un efecto literario más del mismo contraste-relativamente corriente en librillos de este tipo-, y, en realidad, todos conocían el nombre del autor, Paul Géraldy, un escritor hoy razonablemente olvidado que, sin embargo, antes de la guerra había obtenido grandes éxitos con un par de poemarios cuyos títulos resultan ya muy significativos: Les petites âmes, de 1908, y Toi et moi, de 1912, que conoció numerosas ediciones (Géraldy 1912). Éxito, en efecto, sobre todo en el corazón tierno e impresionable del público femenino de la pequeña burguesía a la que esas almitas y esos torpes poemas de amor iban necesariamente dirigidos: "Chérie, explique-moi pourquoi / tu dis : "mon piano, mes roses", / et: "tes livres, ton chien" ...pourquoi / je t'entends déclarer parfois: / "c'est avec mon argent à moi / que je veux acheter ces choses". / Ce qui m'appartient t'appartient!/ Pourquoi ces mots qui nous opposent: / le tien, le mien, le mien, le tien? / Si tu m'aimais tout à fait bien, / tu dirais: "les livres, le chien" / et: "nos roses").

Libros, piano, rosas, perro... y dinero para comprarlos: vamos descubriendo el verdadero fondo de los contrastes. Pero, ibasta con esto! También La Guerre, Madame... fue un librito de éxito, o de relativo éxito, dadas las circunstancias de un libro de circunstancias como éste. Y ya sabemos lo suficiente de su autor como para reconocer el título: la guerra, señora... jse la voy a contar! Público popular que requiere explicaciones emotivas - o público femenino al que al final, en el último contraste, el que se produce entre el heroísmo del narrador 
y la insensibilidad del parte de su muerte, se le romperá el corazón: ¡así de sentimental es la guerra!

Héroes de la vida moderna, soldados desconocidos: en fin, carne de cañón. ¡Qué expresión tan certera! ¡Carne de cañón! Certera, sin ironía ahora, para esa guerra, que necesitó amasar con hierro tanta carne. Más que romperse, ¿qué podrán hacer los corazones sino encogerse, como los hombros, por cierto, ante los despojos de tantos soldados? Pero no adelantemos las cosas, porque carne de cañón, precisamente, no es lo que aparece -o lo que «aparentemente» aparece- en esta novelita de apariencias.

$\mathrm{O}$ en ese cuento, en efecto, escrito como la crónica de un día de permiso del tal caporal Vernier, que desde el tren que lo lleva hacia París ve pasar con impaciencia los letreros que van anunciando los pueblos en las estaciones. Un recorrido en verdad fácil de reconstruir: París no está muy lejos, sino, medido en kilómetros, tremendamente cerca de las trincheras y de los hospitales de campaña desde los que él, por así decir, «regresa».

Aunque podría ser al revés, porque al inicio del cuento es un París más bien «regresado» el que se describe: todo está sorprendentemente igual -incluso más tranquilo, más provinciano, como en vacaciones-, y él, Vernier, no es sino un visitante que, vagando por sus calles, recuerda una imagen que es a la vez la misma y otra. Estaba convencido de que se sentiría un extraño y, en realidad, después de pasear un poco, de Saint Germain al Louvre, «cree» que no lo es. Lo «cree», en efecto, pero eso, ahora lo veremos, ya es mucho creer. Con su uniforme de soldado y su casco (!) atrae, y él lo nota, la mirada disimulada de las gentes en el metro, aunque el olor del metro le resulte a la vez tan familiar, pero desea, en fin, estar sólo, mirar, él también, y no ver a nadie, no ir a las casas vacías de sus amigos muertos o vivos, a la de sus padres o a la suya propia, vacía también. Él es él mismo y otro, pero sin osadía alguna. «Je est un autre»: cualquier consigna de vanguardia se transforma ni más ni menos que en lo necesario por inevitable y por extraño. Yo es otro, yo y otro... «toi et moi»-nueva versión: tú, el soldado -el casco, el capote, el macuto...-, y yo -el soldado, etc.

Lo único que quiere «moi» es llevar a pasear a «toi», ¡qué remedio!: ser un paseante en un París metafísico, en un meta-París, que «moi» aún reconoce, familiar y lleno de calma, y, al mismo tiempo - «toi»- tan calmado como extraño.

En fin, que nuestro amigo el caporal va, y pasea, y mira, y se encanta cándida y tópicamente en el Louvre como lugar de la armonía -así lo llama, después de tanta destrucción que nosotros, sin embargo, no hemos visto-; y compara París con Venecia -qué otra cosa podía hacer un «turista» lleno de «souvenirs»-; y oye hablar de Notre- Dame al claro de luna: ¡contemplad la catedral, como no la habéis visto nunca y como no la volveréis a ver! -aunque 
en la oscuridad de los bombardeos sea el claro de luna, justamente, la luz que ilumina y guía también a los aviones. ${ }^{1}$ Pero no nos fijemos aún en esas ironías involuntarias, porque ya Vernier entra, en fin, en uno de sus restaurantes conocidos y se quita el casco con la naturalidad - eso cree él al menos- con la que se quitaba el sombrero, y se zampa su docena de ostras, y mira cómo la gente come y bebe, charla y ríe despreocupada. ¡Gai Paris! Pero, ¿hay guerra? ¿Y quién se lo pregunta?

De nuevo paseando satisfecho, llega bajo las ventanas de Fabienne. En ese momento nos enteramos de que él tiene, o tenía, algo de seductor, y en cuanto se decida a subir y conozcamos a Fabienne, veremos cuál era el mundo en el que figura -repito, figura: así se cuentan los cuentos- que se movía nuestro hasta ahora simpático pero más bien rudo caporal. «Ella lleva un vestido divino, tan discreto como audaz, en el que su buen gusto y la moda colaboran felizmente». Moda en guerra: interesante, y ya hablaremos, aunque no menos interesante resulta la descripción retroactiva -esa memoria tan prebélica y tan artística-que el narrador hace del apartamento, de cuyas paredes antes colgaban «divertidas» telas de Vuillard y algunas «finas» primaveras de Boggio.

Boggio: debe de referirse al olvidado Emilio Boggio, quien pintó «primaveras» que no podían ser otra cosa; y Vuillard, el gran Édouard Vuillard, ${ }^{2}$ que vivió con su madre, una modista, pintando y pintando, como quien cose, pacientemente, hasta los sesenta años de edad... ¿Cuáles podrían ser esas telas «amusantes»? Algunos, como Coquiot, consideraban a Vuillard un «decorador nato» cuyas obras parecían «papeles pintados»; otros, como Mirbeau, decían que lo que Vuillard necesitaba eran «muros para su magia»; muchos otros, en fin, como al parecer Géraldy, pensaban que Vuillard era un humorista (Coquiot 1914, 200-203 y Mirbeau 1908, XV).

No vamos a entretenernos mucho ahora con lo que Vuillard le decía a Bonnard en una carta enviada pocos meses antes de empezar la guerra: «Gripe por todas partes. Poca pintura»; ni con lo que le comentaba al mismo Bonnard ya militarizado como guardagujas de la estación de Conflans: que allí estaba, junto a su barrera, «vagamente equipado de militar y suficientemente cansado» (Bonnard/Vuillard 2001, 62 y 65). Vagamente, suficientemente... De esas extrañas aproximaciones más bien se hacía su pintura, y ahí lo tenemos, pues, en humorista, decorando las paredes del apartamento de Fabienne, junto a los cuadros de Boggio. Aunque la descripción de ese apartamento no podía con-

1 En la crónica de su experiencia de los bombardeos en París, Azorín escribía que los aviones alemanes llegaban «en las noches de luna llena» y que huían siguiendo la estela del reflejo en el Sena: Azorín 1919, 29 y 42. Más adelante veremos cómo eso ocurría también en Venecia.

2 Vuillard es el autor de los dos dibujos que adornan la «nouvelle édition» de Toi et moi, publicada por la Librairie Stock en 1928. 
cluir tan felizmente. Ahora, las telas - nos dice nuestro caporal- ya no están, y en su lugar sólo hay marcos vacíos: «mucha gripe y poca pintura», en efecto.

Si Vuillard es un humorista, el narrador-caporal Vernier va a experimentar en casa de Fabienne un cambio de humor. Él, que acaba de volver de la guerra -aunque aún no nos ha contado cómo es- se ve sorprendido por la frivolidad de su amiga, preocupada por tantas pequeñeces: que si la calefacción no funciona y hay que pedir el repuesto a Berlín, nada menos (la marca de la caldera es alemana); que si tiene continuas jaquecas (anemia cerebral, lo llama); que si le han requisado el coche, ella que jamás iba a parte alguna caminando... ¡Tantas cosas de las que la guerra es culpable!

No es difícil de imaginar cómo tuvo que sentarle todo eso a nuestro pequeño héroe moderno, nuestro héroe con botas de charol, nuestro soldado, el cual, por desconocido que fuere, o justamente por serlo, cargaba sobre sus hombros no ya el mundo, como Atlas, sino algo mucho más pesado: la banal cotidianidad de sus trece meses de campaña. Huye de la casa irritado: su visión de París ha cambiado completamente. ¡Qué demonios hace esa gente viviendo sus vidas corrientes, por qué van al restaurante, de qué hablan y de qué se ríen! Nuestro pobre Vernier no sabe cuál es la cuestión: esa terrible desaparición de la experiencia que la guerra tecnológica comporta, esa volatilización del tiempo y del espacio, los cuales, en efecto -si hablamos de la guerra de trincheras-, «murieron ayer»-como justo anteayer pensaba Marinetti (Marinetti 1978, 130). O, en fin, esa irrepresentabilidad, esa inenarrabilidad, en la que tanto se insistió entonces: ¿cuál podría ser la experiencia de una guerra en la que todo «democratiza»: la ametralladora, el bombardeo, el gas? Huellas en el gas o en el barro de las trincheras: se las lleva el viento o las borra el agua. No hay nada indeleble. Y hasta los cadáveres son un producto -último producto- de la producción masiva. Como el personaje de la extraordinaria novela de Joseph Roth, Fuga sin fin, allí estaba Vernier, en medio de París, con sus tiendas, restaurantes y confiterías llenos, «y nadie en el mundo era tan superfluo como él» (Roth 1979, 159).

El héroe superfluo, en efecto: pero no exageremos. Cuando Franz Tunda, el protagonista de Fuga sin fin, llega a París, las flores ya se marchitan en la tumba del soldado desconocido. En el «año» de Vernier, en cambio, el soldado desconocido ni siquiera sabe aún que lo es. Mejor no exageremos, pues. Joseph Roth es un gran escritor y Fuga sin fin una novela consciente y demoledora, mientras que Paul Géraldy... bueno, ya sabemos lo que es, y La Guerre, Mada$m e . .$. , un cuento barato. El caporal Vernier no sabe que todas las experiencias del mundo - del mundo de la guerra, quiero decir: «humaredas y neblinas»no sirven para nada. Es decir, no sabe que hay un mundo que se desmorona sin que ningún otro venga a sustituirlo. Ha visto esos marcos sin telas, mucha gripe y poca pintura, pero ese vacío no le ha hablado de su sombría necesidad. 
Al contrario, ¿qué intentará hacer Vernier con él sino llenarlo? Franz Tunda vive como un superfluo, o un póstumo en vida: su «autor», Roth, sabe bien lo que eso significa, y en ningún momento pretende contarnos qué le ocurre: lo que sabemos de él es que lucha a ciegas en la guerra de la antigüedad del lenguaje; en cambio, el pobre Vernier -y Géraldy, su autor- necesita contar la historia, explicarse, darse a entender, porque están ofendidos y se han vuelto recelosos. ¿Habrá que añadir que vanamente, redundantemente recelosos? El caporal Vernier y el poeta Géraldy lo ignoran todo sobre cómo el lenguaje ha conducido a la guerra; lo ignoran todo de la Gran Demolición. Creen aún que el cuento de la guerra puede contarse o, peor, que hay algo que contar, y ya sabemos cómo empieza el cuento: «la Guerre, Madame...».

Hay un salón, remedo del salón literario, donde contar la historia, y no es el salón sin pintura de la frívola Fabienne, sino el de Mme. Baumier, la madre de su viejo amigo Jean, que está como él en el frente. La respetabilísima Mme. Baumier, en fin: madre, matrona, o, sin paradojas, patria. Grandes y hasta gigantescas matronas-patria, formaban la retaguardia sentimental de la carne de cañón que se enredaba en las alambradas y se hundía en las trincheras, y, desde luego, las telas que ornaban los marcos vacíos iban a ser, durante un tiempo, tiernas y masivas maternidades, y no «divertidas» primaveras. A mitad de la guerra, autores como Severini y otros ex-futuristas como él, dejaron de pintar trenes acorazados para ponerse a representar dulces maternidades o anunciaciones. Severini no fue el único que pintó esos cuadros, como no fue Géraldy el único que empezó su cuento diciendo: «la Guerre, Madame...».

Frente a aquellos marcos vacíos de Fabienne y al frío de su calefacción estropeada, al apartamento de Mme. Baumier no le falta nada, aunque lo importante es que ni siquiera es necesario decirlo. Ahí está nuestro caporal junto a una mesa camilla, frente a los visillos del balcón, tomando una taza de chocolate de la marca acostumbrada en la casa. Pero, el caporal Vernier, ¿no se fía de lo que se escribe en la prensa? «Sí -responde Vernier a su anfitriona-, nos llaman soldados valientes, sublimes heridos. Ya no se separa el epíteto del nombre. Es como decir: economista distinguido». Ciertamente, Vernier se ofende aquí también: se ofende ante el tópico periodístico, pero no porque distinga en él ese terrible empobrecimiento, esa liquidación del lenguaje que ha conducido -entre otras cosas- a la guerra, ni porque vea en ese tópico un modo bien medido de «insensibilizar a las personas y vaciar su imaginación» (Kovacsics 2007, 23), sino simplemente porque no se siente aludido, él, él mismo, «moi». Como toda carne de cañón, Vernier lucha con un muñeco de asfalto: creyendo vencerlo quedará sepultado en él. Aunque, en verdad, ya está sepultado. Frente al tópico, Vernier no clama con la rabia de los últimos días de la humanidad, sino no con el lenguaje desgastado del cuento. Contar 
el cuento de la guerra: «la Guerre, Madame...». Señora, madre de soldado: yo le voy a contar qué es la guerra.

¿Cómo podría ser ese cuento? ¿O cómo salir a flote de unas aguas en las que ni siquiera se sospecha estar inmerso? ¿Qué gran ironía y qué tomadura de pelo! ¡Qué pesadísima broma, ser soldado! «Vagamente equipado de militar - decía Vuillard, aquel pintor humorista- y suficientemente cansado». «Vagamente...»: Todos los soldados - movilizados, enrolados, reclutados-son actores tragicómicos del «teatro de la guerra»; ser actor: qué remedio. Nada, en efecto, comparable a esa guerra en cuanto a "sufrimiento e ironía» (Fussell 2006, 15).

Frente al silencio que algunos creen digno del guardián de la casa del lenguaje, los autores sentimentales, populares, como Géraldy, ni creen ni dejan de creer en la palabra, pero tienen que hablar, aunque sea para ganarse la vida en tiempos de hambre: contar y contar, pues, el cuento de la guerra. «Quien tenga algo que decir, que dé un paso al frente y calle», dijo Karl Kraus en alguno de sus aforismos. Pero éste, en verdad, no es el caso. La guerra, al parecer, no ocurre en los últimos días de la humanidad, ni de ella vendrán las noches de Valpurgis, sino en una entretenida extensión de un salón literario o de un salón de té, y quien la explica es poco menos que un explorador, un viajero o - jacabáramos!- un turista.

Así que no sufra, Mme. Baumier -esto dicen las palabras-porque su hijo también toma tranquilamente el té en las trincheras, como ahora mismo hacemos nosotros. «La Guerre, Madame...»-y ahora estoy glosando ya un tanto escorzadamente-, es una especie de alegre reunión célibe, el vestuario de un gimnasio o de un campo de deporte, una pequeña comunidad de héroes -en verdad pequeña, porque son héroes superfluos, soldados desconocidos. Algo así como un lugar en el que hacerse hombre -el colegio mayor, el gimnasio o el burdel -o el cuartel- aunque, ciertamente, con resignación: obviedades, pues, de héroes sin heroísmo. La guerra moderna no es heroica, en fin, viene a decir Vernier, sino resignada. Leyendo su historia, añadamos también que «sin cuento». Si las palabras se deshacen en la boca de Vernier «como hongos podridos», Géraldy, desde luego, «toi et moi», no lo advierte. Ni siquiera cuando, para expresar lo más específico de la trinchera, tiene que dejar de echar mano de las metáforas más manidas y recurrir, simplemente, a las onomatopeyas. En el relamido cuento de alegres jóvenes que van al combate como quien va a un partido de rugby, cantando Auprès de ma blonde, suenan de repente los «piji... piji... piji...» del silbar de las balas, de modo no muy distinto a como se incrustan entre las estrofas de esas cancioncillas de amor viril. Decirle a Mme. Bermier, esa madre, en su salón, en la penumbra de sus visillos, sosteniendo su taza de chocolate, no que las balas silban, sino, bruscamente, exclamar «piji... piji... piji...», parece introducir en el cuento un trozo de realidad excesiva -la onomatopeya se incrusta como la metralla, y el lenguaje se quiebra. Al menos, 
hay que decirlo, esas onomatopeyas no podrían ser acusadas de palabrería, aunque en verdad, ¿qué podemos imaginar que ocurre en esa escena sino, como mucho, una ligera pérdida de compostura?

Marinetti o Carrà, entre otros, construyeron grandes tablas con esas onomatopeyas. «Tavole parolibere», las llamaron: palabras en libertad contra la sintaxis y la prosodia, y contra el discurso razonado, pero no contra la prosopopeya. Hay que ver cómo en esas tablas la onomatopeya es capaz de atribuir propiedades humanas a las cosas inanimadas. Y hay que ver cómo necesita todo tipo de explicaciones. En 1912, por ejemplo, antes de la invención de las «tavole parolibere», en La batalla de Trípoli, en medio de la entusiasta y deportiva narración de la batalla -todos, en gran compañerismo, parecen llevados por la borrachera del partido ganado, o moldeados por una guerra representada en figura de padre que da forma a sus hijos-, en La batalla de Trípoli, digo, también Marinetti introduce onomatopeyas parecidas a las que el caporal Vernier, al parecer falto de otras palabras, privado de la capacidad de describir y relatar, se ve obligado a usar. Por ejemplo: «Cro! Crocro! Cro! Cro! Crocro!» (Marinetti 1912, 17). Esta es la prosopopeya a la que me refería, o la voluntad de prosopopeya: Marinetti cree, entre sueños, encontrarse junto a un lago y oír el croar de una nación entera de sapos en celo. Pero no: es el ruido lejano de las descargas de fusilería. Así que, por lo que se ve, la onomatopeya no va a acabar tan rápido con las metáforas: en este caso, que es el caso de la literatura de guerra más optimista -la que prepara la guerra, justamente-, metáforas naturalistas para las armas y sus sonidos. ¿Cómo llamar a ese esfuerzo? ¿Romanticismo tecnológico o romanticismo de acero, como hará años después el ministro Goebbels (Herf 1984)? Naturalización de las cosas y cosificación de los cuerpos: tal es el doble camino de la maravilla que las metáforas de Marinetti, llenas de bombardeos como tormentas y de cuerpos como máquinas, nos ofrecen. Ahí la onomatopeya es importante porque, paradójicamente, tiene mucho que decir -y hay mucho que decir también sobre ella. En la trinchera, por ejemplo, en medio del ataque, Marinetti siente una «alegría delirante», pero, al mismo tiempo, y puesto que él - periodista y no propiamente soldado- tan sólo tiene un revólver en la mano, tiene que contentarse con «controlar las célebres imágenes de la literatura militar» (Marinetti 1912, 19). Por ejemplo, y como testimonio directo que es $-\mathrm{y}$ bien orgulloso-, nos confirma que las balas «maúllan» (Marinetti 1912, 19), pero solamente cuando son contrariadas por un obstáculo. Entonces, las balas -dice, o cuenta-, hacen molinetes y miran detrás suyo los blancos que no han alcanzado, rebotando despechadas y llorando como gatos abandonados. Bueno, eso escribe Marinetti: así que la onomatopeya -ese ¡miau, miau! de las balas- puede ser explicada, aunque, en verdad, la explicación lo deja muy claro: es en esa mezcla de onomatopeya y 
metáfora, una cosa por la otra, donde se agota la semántica. El lenguaje, en efecto, conduce a la guerra.

El caporal Vernier, lo estamos viendo, usa miles de palabras para contar el cuento de la guerra. Cuento tranquilizador en el que la onomatopeya no es más que una licencia y un respingo: algo que se puede explicar. Allí, señora -dice Vernier para tranquilizar a Mme. Baumier-, en la guerra, la muerte nunca es trágica: al fin y al cabo, especula el caporal, después de la batalla, uno se ducha y se afeita. Como enseñaba Freud, en los sueños siempre sobrevivimos a nuestra propia muerte, aunque eso sí, como espectadores. «Presencié la carnicería como si estuviera en primera fila de un teatro», escribía Jünger en Tempestades de acero, donde el momento que precede a la batalla le recuerda «ese segundo en el que nadie respira, ese segundo que antecede a una representación teatral decisiva, cuando la música se interrumpe y se encienden las candilejas» (Jünger $1983,81)$. En ningún otro sitio como en la guerra mueren los otros, y, aún más, por imposición, El Otro, o sea, el enemigo, el único de quien importa exhibir u ostentar el cadáver y, en su caso - que siempre es el caso- profanarlo (De Luna 2006). Todos sobreviven a su muerte como espectadores: el teatro, en fin, es lo que importa.

O la moda, a través de la cual los poetas y los artistas se habían empeñado con la muerte. Teatro, moda y muerte: según como se mire, esa parecería ser la ecuación de la guerra, y tal vez a través de ella sueña el soldado desconocido - cuyo destino es la fosa común- en dejar de ser el «trabajador» de esa guerra. Pues, ¿no le cuenta el caporal Vernier a Mme. Baumier, ambos a los lados de la mesa camilla y con la taza de chocolate de la merienda en la mano, que en plena ofensiva, mientras corría borracho de nervios y de placer-vaya, como Marinetti-, se puso a cantar a voz en grito el ritmo furioso y salvaje de «ese motivo de Shéhérazade que - dice-todos tenemos en la cabeza desde los últimos Ballets Rusos?». Alguien podría encontrar irónico que ese Ballet se inspirara en un cuento, precisamente, de las mil y una noches. Aunque ironías hay muchas, y en cuestión de guerra y moda, el sufrimiento y la ironía parecen inseparables, y el propio caporal Vernier se ofende al pensar que después de que él muera en el frente la gente continuará paseando frente a los escaparates de las tiendas. La ofensa viene de la incomprensión y convierte a la ironía en involuntaria. Ironía involuntaria hay en la descripción que Vernier hace a Mme. Baumier de la situación de su hijo en las trincheras, o mejor, de su indumentaria: vestido con su capote «azul lunar» y con ese admirable casco, tan moderno y tan clásico al mismo tiempo, «ese yelmo ligero, poderoso y casi religioso que da a los hombres en grupo el aire de un ejército celeste. Gracias a ese azul y a ese casco entrarán en la leyenda». ¿En qué podía estar pensando Géraldy al hacer hablar así a su caporal, sino en una mezcla de ejército en las nubes pintado por algún Ingres, lunar y eléctrico, como un «sueño de Ossián» 
de ocasión, y un casco elegante, como el que algunos artistas franceses se afanaron en diseñar en esos años - cascos, uniformes, complementos...-, como, por ejemplo, hizo Jean Dunand? Alemania tenía que ser también vencida -o sobre todo vencida, según quién lo mire-, en el terreno de las artes decorativas. Aunque, como se ve en las tablas de «diversas secuelas de impactos en cascos de acero franceses» [fig. 2] que por entonces se publicaron, era a la guerra a la que le correspondía dar el último toque a esos diseños, toque que será maestro en el casco de Apollinaire, por ejemplo-y en su cabeza trepanada. A Jean, el hijo de Mme. Baumier, le sienta muy bien ese uniforme, y lo luce mientras en la trinchera, aburrido, sin saber qué hacer, dispara con su revolver a las ratas - para pasar el rato. Esa mezcla de «chic» y «ennui», ¿qué es sino la parodia de la bohemia y de la vanguardia? Ironía involuntaria que tiene en el cuento del pobre caporal Vernier momentos excepcionales: por ejemplo, cuando habla de aquel conocido que querría, a poder ser, recibir alguna pequeña explosión de obús que lo hiriese sólo un poco, en las nalgas, sin desfigurarlo, para obtener así su aureola; o cuando Fabienne se escandaliza de que se envíe a las trincheras incluso a los artistas, pese a que ha oído decir que Vernet «se dejó matar con mucho chic»; o, en fin, cuando recuerda lo que Mme. de Sévigné comentaba durante los primeros días de la campaña de Alsacia: «Ahora comienza la moda de caer herido»».

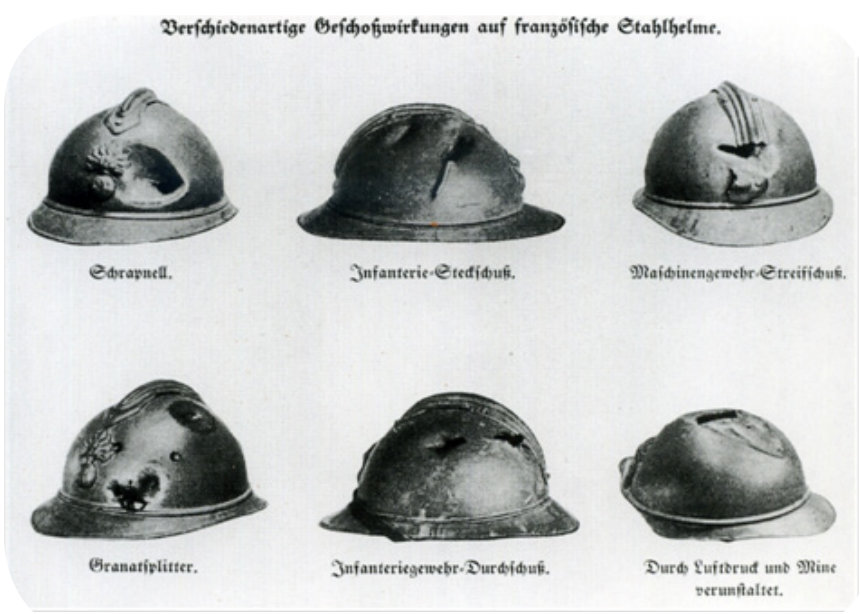

Fig. 2

Mme. de Sévigné: eso sí que es recurrir a la tradición. Las conversaciones, las cartas o las frases célebres de Mme. de Sevigné, ¿no son el ingrediente imprescindible de la gran época clásica? Aunque inmediatamente después de haberla citado, el caporal Vernier reflexiona: «ipero esa moda está durando esta 
vez desde hace ya más de un año!». Sin duda, ahí está la cuestión, y la culminación de la ironía. ¿Cómo puede una moda, ni siquiera la de caer herido, durar tanto? La fugacidad de la moda sigue un ritmo distinto al de la fugacidad de la guerra: otro compás. Al final es la propia guerra el gran modisto, el que trabaja directamente con los cuerpos - con los cuerpos de los otros, bien entendido.

La ironía involuntaria de esos cuentos de guerra, de esa literatura de aventuras, que quiere ser a la vez sentimental y jovial, pero cuya resignación surge por todas partes, atravesada por la perplejidad, viene de no haber comprendido - pero en esa «circunstancia literaria» era imposible comprenderlo- que con la guerra «el lenguaje deja de ser una herramienta para convertirse en un obstáculo». ${ }^{3}$ Los verdaderos humoristas sí lo sabían: por eso fueron parcos en palabras. Veamos, por ejemplo, una tremenda caricatura de Apa [fig. 3]: «Noticias de la guerra: en Alemania empieza a escasear la carne». ${ }^{4}$ Tremenda, porque ahí está la platea maquinal de ese teatro -en silencio. Y lo que escasea, en efecto, es la carne.

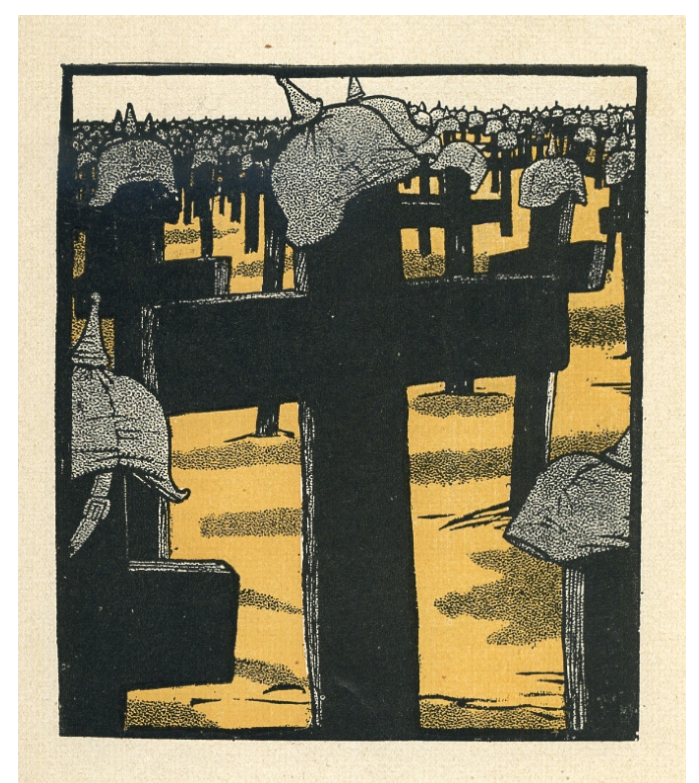

Fig. 3

3 I. Bergman, «Modernolatria» et «Simultaneità», Svenska Bokforlaget, Upsala, 1962, p. 91, citado en Lista 1975, 61.

4 Esta y el resto de caricaturas de Apa (Feliu Elias) mencionadas más adelante fueron publicadas en el álbum Kameraden, Hijos de E. Detouche, Barcelona, 1917, en páginas sin numerar. 
Capotes de azul lunar, cascos modernísimos, heridas elegantes: la guerra como una gran coreografía de los últimos Ballets Rusos... Pero, ¿cómo se había preparado esa gran broma de la guerra como consuelo estético y como fiesta jovial? ¿Quiénes habían dispuesto del lenguaje para hacerle decir que la guerra, como la moda, estaba hecha para nosotros -para todos nosotros? Las vanguardias, desde luego, dominaron como nadie el lenguaje que condujo a la guerra. «Vamos a la guerra bailando y cantando», escribía Marinetti ya en 1912 (Marinetti 1912, 45 y ss.) -y no era, ni muchos menos, el único en hacerlo.

¿En qué salones preparaba Marinetti su particular «demolición» del lenguaje? Entre tantas cosas vale la pena recordar, por ejemplo, que el futurismo de Marinetti -e incluso la obra poética de Marinetti antes del futurismo- fue introducido en Rusia a través del «salón literario» que en su casa de Moscú tenía Mme. Losseff, y me parece impresionante tan solo imaginar cómo debían de leerse en ese salón las páginas exaltadas de La batalla de Trípoli o de los versos libres de El monoplano del Papa, donde leemos cosas como: «siento mi pecho abrirse como un gran agujero / por el que todo el azul del cielo, fresco y torrencial / se cuela deliciosamente»; o, aún mejor para lo que vamos diciendo: «ya pueden las ratas roer graciosamente nuestros manuscritos / porque nuestros motores escriben en pleno cielo/ las claras estrofas definitivas de acero y de oro» (Marinetti 1912.a, 8 y ss).

Me habría gustado, en efecto, ver con qué clase de entusiasmo se recitaban estos versos en el salón de Mme. Losseff, sobre todo teniendo en cuenta historias como la de la princesa Chakhowskoi, la cual, sin duda inflamada por esa misma literatura de «conquista de las estrellas», tras un par de semanas de entrenamiento como aviadora en su Rusia natal, partió hacia Trípoli para ponerse con su monoplano al servicio del ejército colonial italiano, al mismo tiempo más o menos en que Valentine de Saint-Point escribía en el Manifiesto de la mujer futurista que lo que les faltaba a los hombres y a las mujeres era lo mismo exactamente: la virilidad (Saint-Point 1914, 69-74). Aunque la música de esos salones debía de recorrer todos los tonos, y Marinetti bien lo sabía. Lo demuestra, por ejemplo, en el modo en que concluye su manifiesto Abajo el tango y Parsifal, subtitulado Carta futurista a algunas amigas cosmopolitas. Tras una relativamente larga acumulación de razones para dejar de bailar tangos y de escuchar la música de Wagner, escribe: «No olvidéis este último argumento, el único persuasivo para vosotras... amar hoy a Wagner y el Parsifal... Non é piuuuuù chic!» (Marinetti 1914). Ya no es chic: la guerra vendrá a demostrarlo definitivamente, como aquello que ella misma, por necesidad, con humor negro, hace y deshace. De nuevo lo deja bien claro una viñeta de Apa, cuya leyenda dice: «Me parece que esta música perderá mucho después de la guerra» [fig. 4]. 


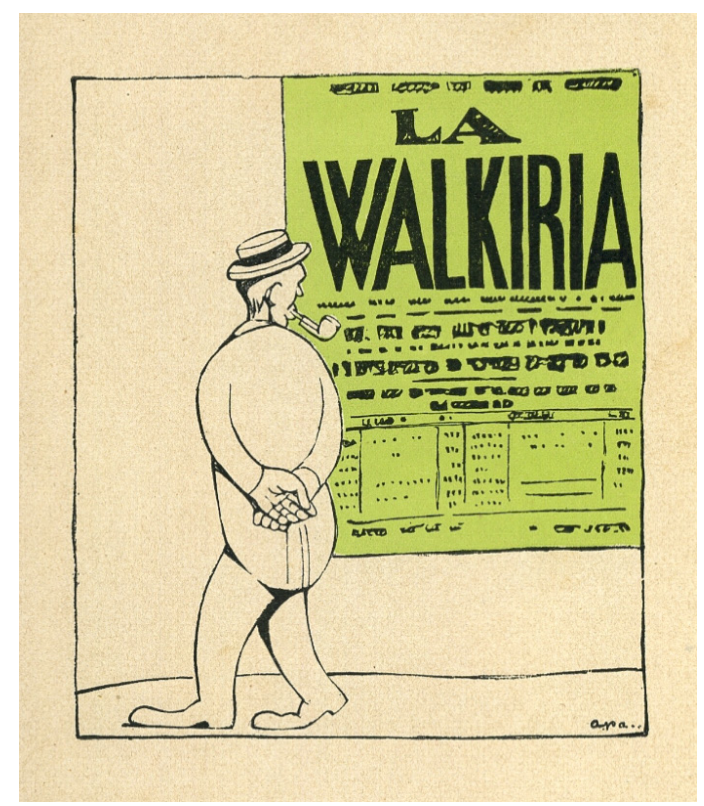

Fig. 4

Los títulos de los tres primeros libros de Marinetti, escritos antes de proclamarse futurista, no pueden ser más elocuentes: La conquista de las estrellas, Destrucción y La momia ensangrentada (Marinetti 1904). No atendamos ahora al tono romántico folletinesco que esos títulos dan a entender, y dejemos correr la cuestión de si en esos libros, Marinetti, orquestando los elementos, emula a Víctor Hugo, a Chateaubriand o a Verhaeren. Más bien fijémonos en cómo los tres títulos parecen definir, en perfecto y siniestro encadenamiento, los pasos de un proyecto y sus resultados. La ascensión a los cielos del primer título, La conquista de las estrellas, tendrá como primer resultado lo que dice el segundo: Destrucción. O, a qué se asciende al cielo, sino a bombardear, como explícitamente se hace de la manera más fantástica en El monoplano del Papa, donde la bomba que se lanza a los enemigos es el propio Papa, en carne, hueso y pontifical; o en La batalla de Trípoli, donde, pese a la voluntad de crónica, no falta la fantasía. Los vuelos aéreos relatados por Marinetti en esa batalla ocurrieron de verdad: él pudo contemplar la gigantesca masacre desde el avión del capitán Piazza, observar los movimientos de tropas, ver más que nadie y gritar arengando a las tropas, como un gran director de escena, a gran velocidad, desde 80 metros de altura. O como un escultor sin medida: «iAdmirad... -exclama- las locas esculturas que nuestra inspirada artillería talla a golpe de metralla en las masas enemigas!» (Marinetti 1912, s/p). Marinetti 
estuvo en verdad en esos vuelos, y todo eso le ocurrió, pero le ocurrió como culminación de sus propias fantasías.

La batalla de Trípoli, «vivida y cantada por Marinetti», como dice el subtítulo del libro, tuvo lugar el 26 de octubre de 1911. De modo que a escasos tres años de las primeras grandes demostraciones de vuelo en París, las grandes fantasías de la «conquista de las estrellas» se cumplían literalmente. Los aviadores italianos fueron los primeros en bombardear a la población civil, desarmada e indefensa, de los oasis de Taguira y Ain Zara: siete bombas dejadas caer desde el avión sobre unas gentes que veían un avión por primera vez -y última. Siete bombas «altamente explosivas», como dijo la prensa de la época, «lanzadas desde el mismísimo cielo como algo definitivo e irrefutable» (Lindqvist 1999, entrada 4). Definitivo e irrefutable, en efecto, como la eliminación de la prosodia, como las aliteraciones, las paronomasias, la duplicación de sustantivos, el paratactismo, la reducción de los verbos al infinitivo, la supresión de la puntuación, las onomatopeyas... las primeras palabras de guerra. Desde el «monoplano del Papa», sobrevolando los «océanos de bayonetas», Marinetti exclama simplemente, para concluir: «iiDestruir, hay que destruir, hay que destruir sin parar!!» (Marinetti 1912.b, 346). Según su autor, El monoplano del Papa fue concluido en las trincheras de Sidi-Mesri, cerca de Trípoli. Fantasía por realidad y realidad como fantasía, la movilización total que supone la «conquista de las estrellas» no implica otra cosa que la «destrucción» total.

He aquí algunas de las cosas que en La batalla de Trípoli Marinetti ve desde las estrellas: «Un artillero que avanza pesadamente con el sable salpicado de grumos de sangre, casquillos y barro, aullando con las mandíbulas dolorosamente desencajadas: ¡ocho, he matado a ocho!». O: «Un sargento con la boca amordazada con trapos ensangrentados que levanta gesticulando las manos hacia mí para indicar, con sus diez dedos bien separados, que ha matado a diez» (Marinetti 1912.a, 57). Nada iguala, dice Marinetti, al esplendor épico de este sargento. Pues bien, ahí tenemos, en fin, el título que nos faltaba: las momias ensangrentadas.

Primeras palabras de la guerra: la conquista de las estrellas, destrucción, momias ensangrentadas... A la guerra misma le corresponde el resto del trabajo, como poeta, como escultor o como arquitecto, como gran hacedor de fantasías. Por ejemplo, como poeta, en las cancioncillas que según Marinetti los soldados cantan a voz en grito durante el asalto a las puertas de Trípoli: «Di’ biondina, lo vorresti mai/ quell'uccellin, lin, lin, lin lin... / quell'uccellin, lin, lin, lin lin... / quell'uccellin, lin, lin, lin lin...» (Marinetti 1912.a, 56). Cancioncilla onomatopéyica, pues, y péndulo futurista, al mismo tiempo. Por ejemplo, en Zang tumb tumb, versos libres sobre la batalla de Adrianópolis, o en 8 almas en una bomba -novela explosiva-, no sólo leemos -o vemos [fig. 5]- las habituales onomatopeyas presentes en los mismos títulos, siempre aparentemente 
distintos pero siempre equivalentes, sino también, por ejemplo: «Miembro virildesflorar- vulva- fecundación- besos...» seguido de -o paralelo a: "Granada de metralla- rajar- cuerpo enemigo- guerra- lágrimas de sangre...»_(Marinetti 1912.c; 1914.b, 53). Versiones mecánicas, pues, de aquel amoroso «uccelin», aunque ya sin pizca de gracia ni de malicia.

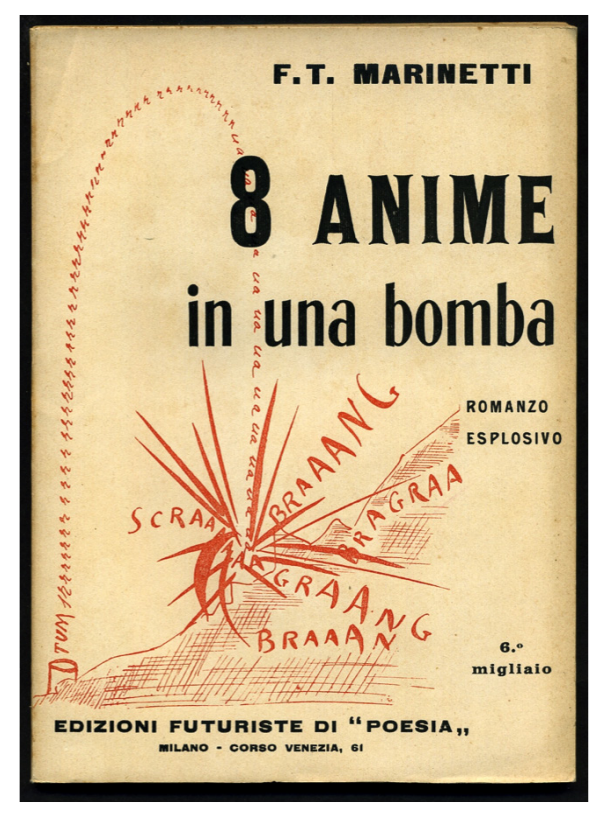

Fig. 5

$\mathrm{O}$, por ejemplo, como escultor, y bien moderno, dando cumplida cuenta de aquel título de otro de los manifiestos de Marinetti, El hombre multiplicado y el reinado de la máquina, en donde habla de «la futura e inevitable identificación del hombre con el motor», de la creación de un «tipo inhumano y mecánico», de los «interruptores de la potente electricidad fisiológica», del olfato mecánico, del emparejamiento con motores, del fatal desarrollo de paletas en la cara anterior del esternón, de modo que el hombre del futuro tendrá el cuerpo moldeado no ya como el mejor aviador, sino como un avión (Marinetti, 1978, 74-82), etc. etc.

¿Cómo seguir, si es que eso es posible, sin pensar en la gigantesca cirugía y en la colosal ortopedia a que dio lugar la guerra, y que los pavorosos tomos de Friedrich, Guerra contra la guerra (1930), hicieron saltar a los ojos de los supervivientes, convirtiéndose, primero, en escuela de artistas, y luego en gran espectáculo, a través los muchos libros morbosos que, a lo largo de los años, le siguieron [fig. 6]? Escuela de artistas de posguerra, desde luego, aunque la primera palabra ya estaba dicha en la preguerra futurista, y de qué modo. A 
Boccioni, su Fusión de cabeza y ventana le pareció un fracaso, y probablemente fue él mismo quien la destruyó junto con otras de sus obras de este momento [fig. 7]. En las fotografías en las que el fantasma de esa escultura ha sobrevivido vemos que, en efecto, más que «fusión» de cabeza y ventana como «continuidad en el espacio», que diría el Manifiesto técnico de la escultura futurista (Boccioni 1914, 363 y ss), ${ }^{5}$ lo que tenía lugar en esa obra era un doloroso empalamiento: hay fragmentos de ventana bien visibles, $y$ hasta un mechón de cabellos de mujer, pero también partes perfectamente modeladas como en cualquier escultura tradicional, de modo que da la impresión de que ahí, a la escultura, a ese arte que, no por casualidad, sin duda, Boccioni creía el más «momificado», le están aplicando su propio tormento.

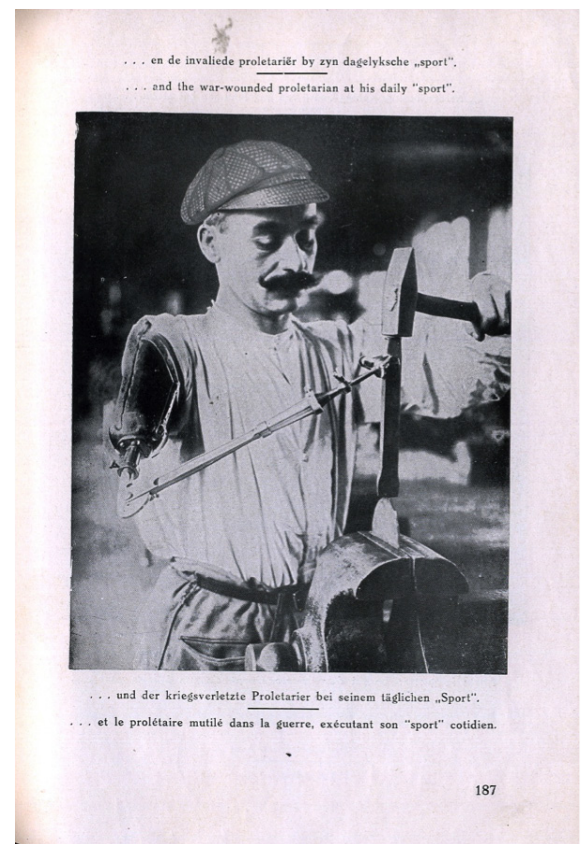

Fig. 6

De otra de sus obras, Cabeza + Casa + Luz, dijo Roberto Longhi que nunca llegaría a ser «cabeza-casa-luz». Fracaso del escultor «haciendo», pues, pero no «anunciando», porque en lo que atañe a ese tipo de «fusiones», la guerra será también «definitiva e irrefutable»: la gran maestra de la fusión. Y, en efecto, puestos a introducir la realidad en la obra de arte, tal como Boccioni reclamaba en la culminación de su manifiesto, ¿quién lo conseguiría mejor que la guerra

5 Las esculturas citadas aparecen reproducidas en las láminas de este libro. 
misma? De nuevo un caricaturista -Picarol en este caso, en una de las viñetas de Kultur-, más allá de cualquier collage o assemblage, con magnífica sencillez, dejaba las cosas bien claras: «El pintor: "¿Desea que le haga un retrato? ¿Y cómo ha de ser: al óleo?”. El militar: “¡Al petróleo!”»"

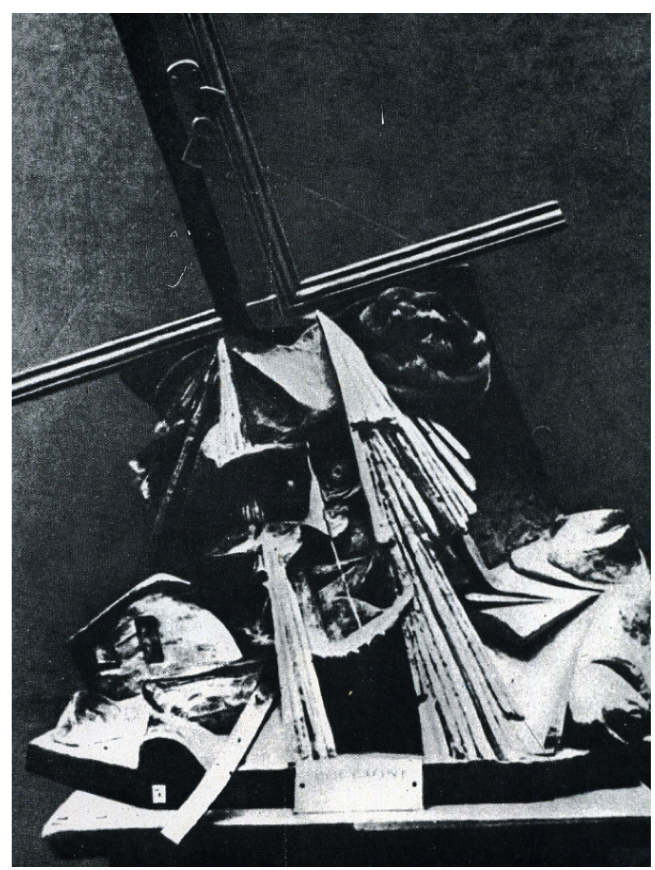

Fig. 7

Primeras palabras de la guerra, pues, de nuevo. La escultura de Boccioni, ¿qué será sino un destello didáctico? Esta «primera» escultura de guerra, anuncio y proclama, está diciendo: He aquí «la Guerre, Mme. Lossef...», he aquí «la Guerre, Mlle. Chakhowskoi...». Porque, por otra parte, y puestos a denostar los museos - como hacían Marinetti y los futuristas, iniciando una cantinela que sería repetida por todas las vanguardias-, ¿quién podría igualar los trabajos de la guerra en cuanto a iconoclasia?

Echemos una ojeada a las fotografías que Stefano y Siro Serafin tomaron de los yesos de la Gipsoteca Canoviana [fig. 8] después del bombardeo de las tropas austriacas (AA.VV. 2004).

6 Esta y el resto de caricaturas de Picarol (Josep Costa Ferrer) mencionadas más adelante fueron publicadas anónimamente en el álbum Kultur. Anthologie barbare des temps modernes, Librería Española y Extranjera, Barcelona, París, (1917), en láminas sin numerar. 


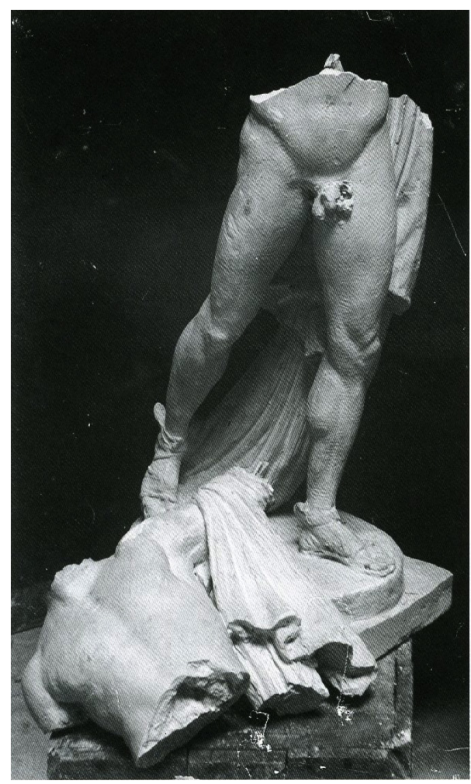

Fig. 8

«Deseamos demoler los museos y las bibliotecas», decía en su punto décimo el manifiesto futurista, pero lo que vemos en las fotografías de los hermanos Serafin -esos yesos reducidos a pedazos-, nos habla de algo más que de la realización de una siniestra fantasía: nos habla, sobre todo, de la simultaneidad con la que se produce la desaparición de la figura humana «representada» en el arte y la histerización de la «verdadera» figura (deformada, mutilada, etc.) visible a través de otros medios; del modo en que la Naturaleza ya no es la imagen de lo incontrolable, sino lo artificial convertido metafóricamente en «otra Naturaleza»; del hombre de acero tanto como de la «tempestad» de acero, y de la guerra como de una gran catástrofe «natural». Nos habla, en fin, de una iconoclasia imperfecta, de cómo el arte se vuelve «monocromo» mientras crecen hasta el límite de lo impensable las imágenes del horror, como «contactos» o huellas directas del horror mismo. La masa modelada por la metralla es la gran obra de arte de los últimos días de la humanidad: masa de yeso o de carne, aunque la carne escasee.

Pero como la metáfora preferida del futurismo enseña, de cualquier cosa puede hacerse carne, y viceversa. Hasta los «pasadistas» lo entendieron así: la guerra es la gran maestra. Por ejemplo, Camille Mauclair, en El arte asesinado (Mauclair 1917), antropoformiza el arte ya desde el mismo título, aunque sea como «subversión» provocada por su propio asesinato - un deseo, por cierto, ese de asesinar al arte, tan común en las vanguardias. Lo primero que sorprende 
del texto, sin embargo, es el tono altamente irónico gastado por Mauclair. Y no se trata, en este caso, de ironía involuntaria, sino conscientemente construida en los contrastes que, con tantas obras de arte mutiladas, pueden hacerse. El de Mauclair es, literalmente, un discurso sobre lo que queda, en el que la «kultur»-no la guerra- es presentada como tecnología de destrucción. Estas son las claves de la descripción teatral de los combates: «kultur» contra arte, tecnología contra espíritu, y espíritu como carne; el «vandalismo científico» tiene como resultado «la carnicería de las estatuas». La piedra de las estatuas, pues, se carnifica, con lo que la humillación se produce en la piedra, en la carne y en el espíritu: ahí está la gran y última unión entre dolor e ironía, su definitiva «fusión». De todas las obras mutiladas que muestran las fotografías que acompañan el texto de Mauclair, la del gran cristo de la iglesia de Revigny [fig. 9], es sin duda la más impresionante. Lo que las estatuas clásicas tienen, busto, este Cristo ya no lo tiene, y lo que este Cristo tiene, miembros colgantes -un brazo, una mano, unos pies- es lo que les falta a las estatuas clásicas. La guerra es el sueño de Pigmalión invertido: bien lo anunciaban las metáforas del futurismo.

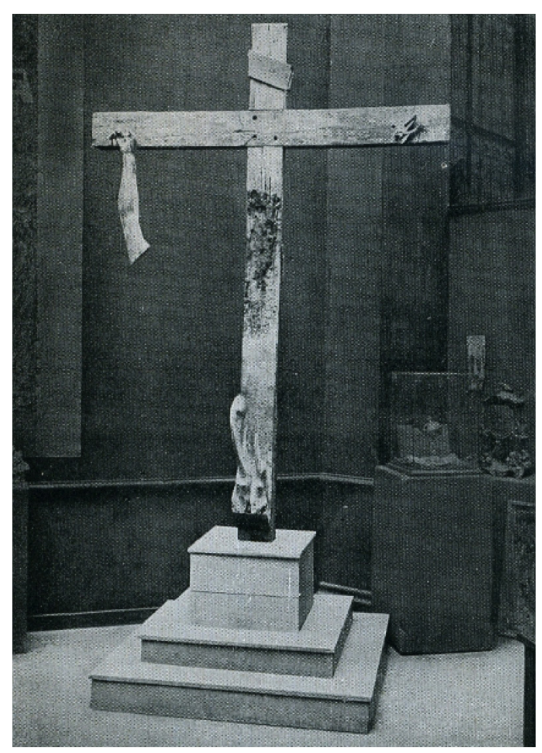

Fig. 9

Aunque, iqué importa si escasea la carne! De ese Cristo no queda más que una mancha de humo, una sombra de una sombra. Así ocurre en los grandes espectáculos del progreso que Marinetti propone sin descanso, sin detenerse ni un momento, como el progreso impone. Escribe, por ejemplo, en La guerra 
eléctrica: «guardaos de criticar al progreso: el progreso siempre tiene razón». Eso escribe, pero no basta. Permítanme esta larga cita: «Del Extremo Oriente acaba de llegarnos el más claro, el más violento de los símbolos futuristas. Existe actualmente en Japón un comercio de los más extraños: el comercio del carbón de huesos humanos, desde que todas las fábricas de pólvora comenzaron a trabajar en la preparación de una nueva sustancia explosiva más mortífera que cuantas se conocen hasta hoy [...] A este fin, innumerables comerciantes japoneses exploran en todos sentidos los vastos campos de batalla manchurianos sembrados de cadáveres. Se descubren enormes zanjas febrilmente y grandes montones de esqueletos se destacan aquí y allá en los amplios horizontes belicosos. Siete kilos de huesos humanos sólo cuestan 92 kopecks, que no es precio subido ciertamente. Los comerciantes japoneses que dirigen este comercio futurista no compran cráneos, pues los cráneos, según parece, no reúnen las condiciones necesarias. Yo comparto su desdén por esos lamentables cofrecillos de la antigua sabiduría. Compran, por el contrario, a montones todos los demás huesos para expedirlos al Japón, y la estación de Benikou aparece a lo lejos a los viajeros del Transiberiano como una gigantesca pirámide blanquinosa: esqueletos de héroes que serán luego machacados en morteros por sus hijos, parientes o convecinos y bárbaramente vomitados por las piezas de artillería, allá muy lejos, contra los pálidos rostros alineados de los ejércitos enemigos» (Marinetti 1978, 107-108).

Muchas palabras; sin palabras. Así son las fantasías cumplidas, los sueños que se hacen realidad. ¿Qué tendrá de extraño que Marinetti cite a menudo una frase de un aviador, Blériot, que dice: «Todavía necesita el progreso muchos cadáveres»»? ${ }^{7}$ Si lo dice un aviador no hay problema, porque los cadáveres llenarán un océano: ¿qué mejor espectáculo que el del mar muerto desde las estrellas?

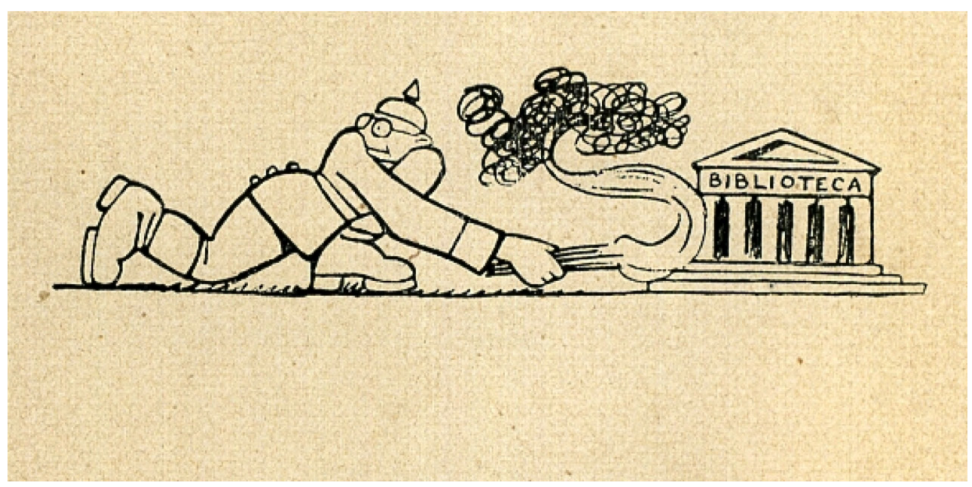

Fig. 10

7 Por ejemplo en «Lo que nos separa de Nietzsche» (Marinetti 1978, 96). 
La «demolición de los museos y las bibliotecas», pedía el manifiesto futurista. El caricaturista francés Tap interpretó esa idea con pulsión de artista moderno. Al pié de su caricatura dice: «Impresión de arte: qué belleza» (GrandCarteret 1916, frontispicio). Apa, por su parte, en Kameraden, la interpretó también, aunque de un modo aún más simple, con un monigote [fig. 10]. Tal vez no era necesario mucho más.

Antes de que anarquistas como Pier Carlo Magnani acusaran a Marinetti de ser un «futurista de la edad de piedra», él había sentido gran admiración por ellos y por sus méritos, empezando, claro está, por las lecturas del George Sorel de La huelga general y la violencia, o del Tommaso Monicelli de Vanguardia socialista, o del Ottavio Dinale que dirigía una revista cuyo título era La demolizione, precisamente, con la que el propio Marinetti llegó a colaborar. Pero hablando de demoler, ¿cómo olvidar ese poema del propio Marinetti, publicado originalmente como una «Invocación [...] contra las ciudades» y vuelto a publicar en la revista Poesia como «Elogio de la dinamita»? ${ }^{8}$
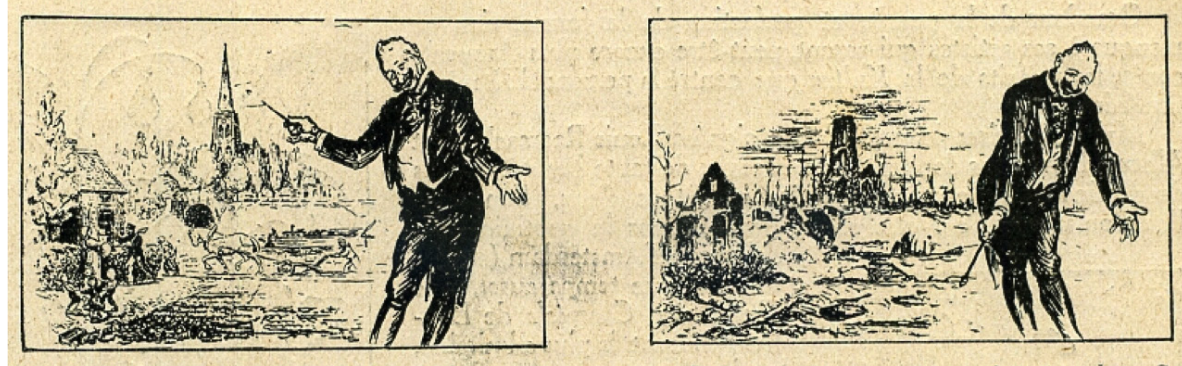

Fig. 11

De entre todas las fantasías la demolición es la más grande: la más aclamada «beauté de la guerre», como la llamaría Aragon, y, finalmente, el gran espectáculo. La demolición de Roma, Florencia, Venecia... «las tres heridas purulentas de Italia», es lo que esperaba contemplar Marinetti desde su monoplano: el gran teatro de variedades. «Al terremoto, escribe Marinetti, su único aliado, dedican los futuristas estas ruinas de Roma y Atenas» (Marinetti 1978, 49 y 94). También la guerra, surgiendo por los Alpes, sabe que en Italia, como en cualquier parte, tendrá mucho trabajo, tal como muestra una caricatura de Apa en la que la guerra se asoma babeante sobre el horizonte de una ciudad hecha toda de monumentos. La demolición es el gran tema de la vanguardia y

8 F.T. Marinetti, «Invocation... contre les villes» (Marinetti 1904.b, 221-226; $i d$., «Éloge de la dynamite» (Marinetti 1906). Sobre la relación de Marinetti con el anarquismo, vid.: Pier Carlo Massini, «Noi vogliamo glorificare il gesto destruttore dei libertari», en AA.VV., Il Futurismo (1976, 88-89). 
de la guerra, pero la ironía pertenece a la guerra, no a la vanguardia. Una caricatura publicada en Life, por ejemplo [fig. 11], nos muestra la perfecta escena de prestidigitación de los tiempos modernos -teatro de variedades, en efecto, como quería Marinetti. La leyenda dice: «señoras y señores, aquí ven Bélgica, y aquí no la ven». Y otra caricatura, de Luce, nos enseña, sin atenuantes, el verdadero sentido del teatro de la guerra, su significado más profundo: «-Si el dios de la guerra nos abandona, ¿qué haremos? -Montaremos una empresa de demoliciones» (Grand-Carteret 1916, 16 y 20). Y aún con mayor agudeza lo vio Friedrich cuando encabezó las fotos de cuerpos mutilados y deformes, de cirugía brutal y cruda ortopedia, con la imagen de un edificio en ruinas -una iglesia- a cuyo pié escribió: «He aquí los trabajos de restauración del capitalismo» (Friedrich, 1930, vol. I, 183) [fig. 12]. Restauración, demolición, ironía: «La Guerre, Mme...».

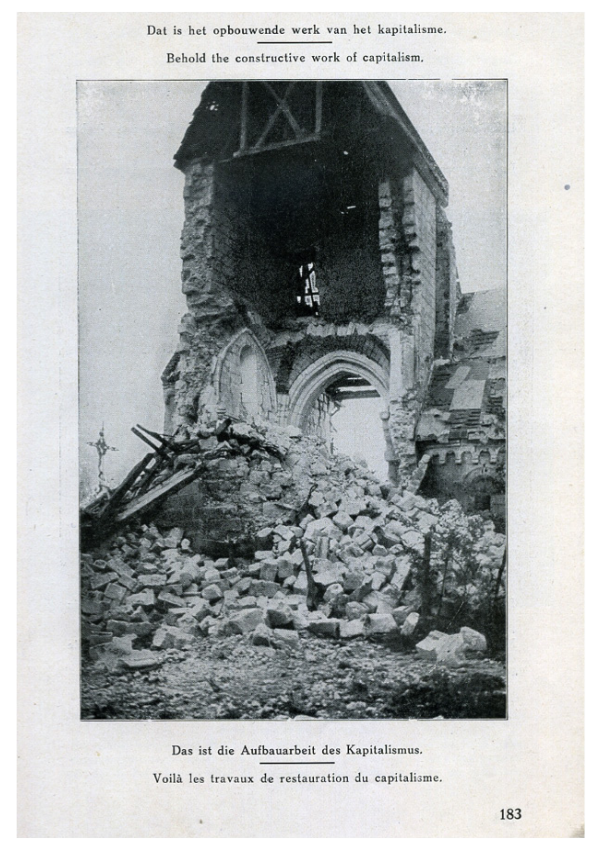

Fig. 12

La guerra confirmó dos cosas en las que la vanguardia estaba empeñada: la primera, el triunfo de la aviación o, por decirlo así, la conquista de las estrellas; la segunda, que las casas y los monumentos, las ciudades enteras, iban a ser demolidas: o sea, la destrucción; y todo ello a costa, irónicamente, claro está, como una gigantesca broma, de las momias ensangrentadas. Pero, ¿a qué nos lleva la demolición, sino a despejar el terreno para la construcción 
posterior y, por tanto, a la arquitectura? «La arquitectura futurista, exclamaba Sant'Elia en su manifiesto, se desprenderá de la tradición, volverá a empezar desde el principio, abolirá lo decorativo, se organizará en grandes agrupaciones de masas, durará menos que nosotros mismos» (Sant'Elia 1914), etc. etc. etc. Hablemos, pues, de arquitectura de guerra, de arquitectura futurista.

En 1918 Ugo Ojetti publicó Los monumentos italianos y la guerra, un álbum fotográfico que nos muestra grandes edificios fueron protegidos de los bombardeos enemigos. En su texto de presentación leemos, por ejemplo: «Los hidroaviones llegan sobre Venecia casi siempre en noches de luna, cuando es claramente visible desde lo alto, circundada de agua y entrecruzada por canales que reflejan sus perfiles tan claros como sobre una carta topográfica» (Ojetti 1918, 17). La respuesta a esta evidencia de luz de luna -la auténtica enemiga- es un mundo transformado en sólidos geométricos, como en un juego de arquitectura; un mundo infalible, en fin, en el que los dones de Froebel se han apoderado de todo. En las fotografías vemos altares y fuentes, templos y palacios, catedrales enteras, desaparecer en el interior de gigantescos embalajes de madera [fig. 13]. Nada queda de esos grandes monumentos sino una forma esencial, simplificada, disminuida. Ya no podemos ver-ni tocar- las molduras, los pliegues, las arrugas que las manos del artesano o el paso del tiempo labraron en los mármoles preciosos. Todo ha quedado envuelto en un cajón cuya lisa homogeneidad no es sino la contracción de un tiempo instantáneo, sin trabajo.

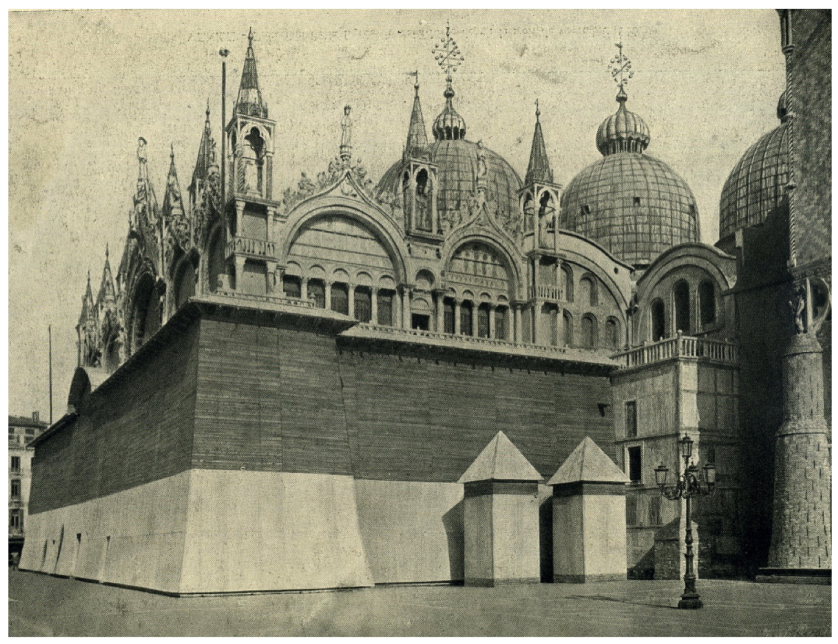

Fig. 13

La guerra no ha dejado nada sin embalar-todo a ras-y, de hecho, ¿a qué nos recuerdan esas cajas, sino a la barraca del capitán Savino, que comandaba 
la batería instalada en las trincheras del oasis de la Bumeliana, en La batalla de Trípoli?: «Una barraca, como escribía Marinetti, hecha con cajas de municiones rellenas de arena». Marinetti, Savino y el capitán De Rossi están comiendo en ella los macarrones más ricos del mundo: «calientes y rojos», dice Marinetti (Marinetti 1912.a, 7-8). Estos son los verdaderos dones de Froebel que entusiasman a los arquitectos modernos: tenderete, barraca, embalaje, casa o caja, o casa de cajas, pero de cajas de municiones. Ahí no había nada que desembalar; en lo que Ojetti nos enseña de Los monumentos italianos y la guerra, tampoco. Lo que vemos en ese libro es como los más grandes monumentos se rinden a su embalaje de tablones: los pilares acritanos, las estatuas de reyes, el monumento a Colleoni, el Gattamelata, la esquina de San Alipio, los caballos de San Marco o el mausoleo completo de Gala Placidia, ahí están, bajo esas cajas cubistas. El arte y la arquitectura han sido embalados en defensa propia: las excusas de la guerra y de las vanguardias no son tan distintas. Pues, ¿no proponía Marinetti, en uno de sus manifiestos más premonitorios, el titulado $L a$ única solución al problema financiero, la venta de todo el patrimonio artístico italiano como «única solución», precisamente (Marinetti 1915)?

La guerra hará lo imposible por cumplir con la vanguardia. Si no, ¿qué significan esas guías turísticas que Michelin, por ejemplo, publicó inmediatamente después del armisticio? Guías ilustradas Michelin de los Campos de Batalla: las batallas de Reims, la de Verdún, las del Marne... ${ }^{9}$ Visitas a los campos de batalla, a las trincheras, a las fortificaciones abandonadas, a los restos de alambradas, a los bosques calcinados, a los pueblos destruidos, a los monumentos demolidos, a las obras de arte desaparecidas -visitas al vacío acompañados por planos fantasmales en los que unos puntos negros señalan los lugares exactos donde cayeron los obuses en los sucesivos bombardeos de la catedral de Reims, por ejemplo. Con la mayor naturalidad, esas guías tutelan, llevan, conducen al turista de guerra hacia lo desaparecido, hacia lo que no está, hacia la nada -es decir, hacia el futuro. Y, siendo futuristas como son, ya es ironía que el tiempo verbal usado en estas guías tenga que ser el pasado. Por ejemplo, al azar, aún en la guía de Reims, ${ }^{10}$ subrayo: «Sala de Tau o sala de los reyes. Ver plano página 33. Al final del patio, había una gran sala [...], se accedía a ella por una escalera de hierro forjado de finales del s. XVIII [...], un templete formaba un porche al final de la escalera [...], tenía dos plantas... etc. etc.». Al azar también: «La Iglesia de San Pedro, en Tinqueux, completamente destruida, tan sólo contenía una curiosidad: una adoración de los pastores, pin-

9 Guides illustrés Michelin des champs de bataille, Michelin \& Cie., Clermont-Ferrand, Londres, Milltown N.J., 1917-1921, 29 vols.

10 El volumen se titula Reims \& les batailles pour Reims, 1914-1918, y fue publicado en 1919. Las citas que siguen: pp. 135-139. 
tada sobre madera en el siglo XVI, con marco de la misma época, que colgaba en el lado izquierdo de la nave». O por ejemplo: «Saint Thierry. Ver itinerario p. 134. La iglesia de Saint Thierry presentaba algunas partes remarcables: el pórtico, la nave y la tribuna. El pórtico, del siglo XII, se cubría con un tejado del XVII. En el interior había una sillería gótica y un bajo relieve del siglo XVI representando el martirio de San Quintín. Todo se encuentra en ruinas», etc. etc. etc. Parece que el final de la guerra se llena de melancolía, sobre todo entre aquellos que nacieron bajo el signo de Saturno [fig. 14].

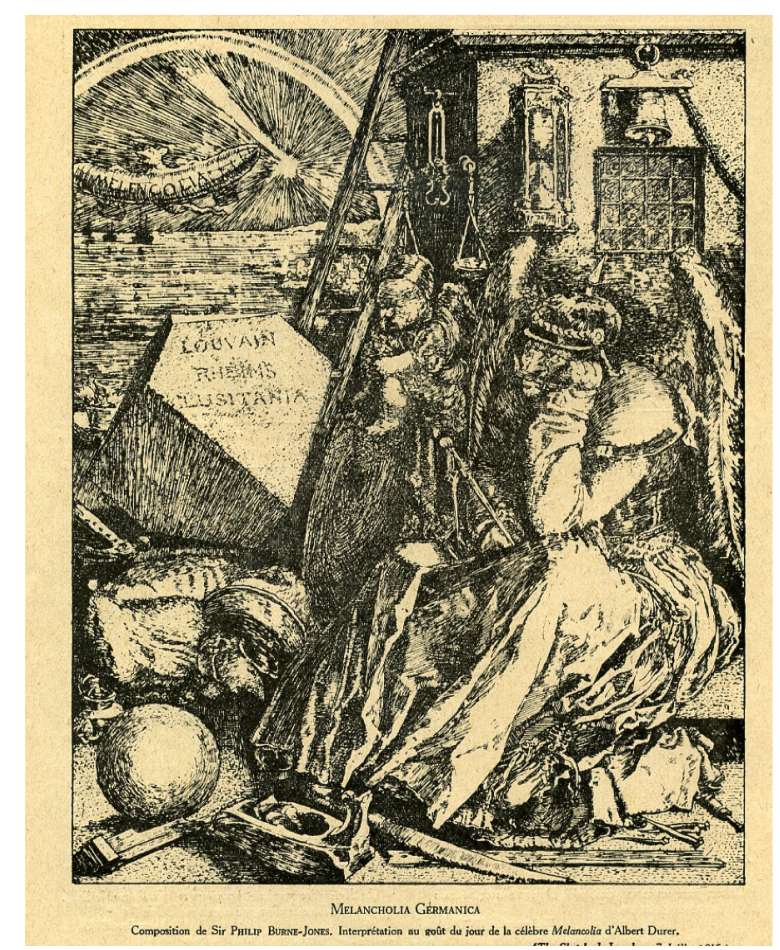

Fig. 14

\section{REFERENCIAS BIBLIOGRÁFICAS}

APA 1917 (a): Kameraden. Barcelona: Hijos de E. Detouche.

APA 1917 (b): Kultur. Anthologie barbare des temps modernes. Barcelona/París: Librería Española y Extranjera. 
AZORÍn 1919: París bombardeado. Madrid: Renacimiento.

Boccioni, U. 1914: Pittura Scultura Futuriste (Dinamismo plastico). Milán: Edizioni Futuriste di Poesia.

COQuiot, G. 1914: Cubistes, Futuristes, Passéistes. Essai sur la jeune peinture et la jeune Sculpture. Paris: Librairie Ollendorff.

FRIEDRICH, E. 1930: Krieg dem Kriege! Guerre à la guerre! War against War! Oorlog aan den Oorlog!, 2 vol. Berlín: Internationales Kriegsmuseum.

FUSSELL, P. 2006: La Gran Guerra y la memoria moderna. Madrid: Turner.

GÉRALDY, P. 1908: Les petites âmes. Paris: Léon Vanier

GÉRALDY, P. 1912: Toi et moi. Paris: Librairie Stock.

GÉRAldy, P. 1916: La Guerre, Madame... Paris/Zurich: Georges Crès et Cie Éditeurs. GRAND-CARTERET, J. 1916, Caricatures et images de guerre. Kaiser, Kronprinz et Cie.

[1914 en el periódico La Guerre Sociale]. Paris: Librairie Chapelot.

HERF, J. 1984: Reactionary Modernism. Technology, Culture, and Politics in Weimar in the Third Reich. Cambridge: Cambridge University Press.

JÜNGER, E. 1983: Tempestades de acero. Barcelona: Tusquets.

KOVACSICS, A. 2007: Guerra y lenguaje. Barcelona: Acantilado.

LINDQVist, S. 1999: Historia de los bombardeos. Madrid: Turner, entrada 4.

LISTA, G. 1975: «Sur un vol de Beaumont ou "Le monoplan du Pape"», en Europe. Revue Littéraire, n. 551, marzo, 1975, p. 61.

marinetti 1902: La conquête des étoiles. Poème épique. París: Éditions de la Plume. MARINETTi 1904 (a): La momie sanglente. Milán: Éditions du Journal Verde e Azzurro. marinetTi 1904 (b): Destruction. Poèmes lyriques. París: Léon Varnier Éditeur. MARINeTti 1906: «Éloge de la dynamite», en Poesia, II, n.6-8, julio/septiembre. MARINetTi 1912 (a): La bataille de Tripoli. Milán: Edizioni Futuriste di Poesia.

MARINetTi 1912 (b): Le monoplan du Pape. Roman politique en vers libres. París: E. Sansot et Cie.

MARINetTi 1912 (c): Zang tumb tumb. Parole in libertà. París: Tipografia Elzeviriana.

MARINETTI 1914 (a): À bas le tango et Parsifal! Lettre futuriste circulaire à quelques amies cosmopolites qui donnent des thès-tango et se parsifalisent. Milán: Direction du Mouvement Futuriste.

MARINETTi 1914 (b): 8 anime in una bomba. Romanzo explosivo. Milán: Edizioni Futurist di Poesia.

MARINETTI 1915: L'unica soluzione del problema finanziario. Milán: Direzione del Movimento Futurista.

MARINETTI 1978: Manifiestos y textos futuristas. Barcelona: Ediciones del Cotal.

MASSINI, P. C. 1976: «Noi vogliamo glorificare il gesto destruttore dei libertari», en AA.VV.: Il Futurismo. Milán: Fratelli Fabbri Editori. 
MAUCLAIR, C. 1917: L'art assassiné, número especial de L'art et les artistes, París. MIRBEAU, O. 1908: «Préface» al catálogo de la venta de la Collection Thadée Natanson Paris: Hôtel Drouot.

OJETTI, U. 1918: Los monumentos italianos y la guerra. Milán: Alfieri \& Lacroix, Milán. ROTH, J. 1979: Fuga sin fin. Barcelona: Icaria.

SAINT-POINT (de), V. 1914: «Manifesto della donna futurista», en AA.VV., I manifesti del Futurismo. Prima serie. Florencia: Lacerba.

SANT’ELIA, A. 1914: L’architettura futurista. Manifesto. Milán: Direzione del Movimento Futurista.

Terrasse, A., (ed.) 2001: Bonnard / Vuillard. Correspondance. París: Gallimard. AA.Vv. 2004: La bellezza violata. I danni della Grande Guerra sulle opere del Canova. Possagno: Museo Gipsoteca Canoviana.

Juan José Lahuerta es Profesor de Historia del Arte y la Arquitectura en la Escuela de Arquitectura de Barcelona y jefe de las Colecciones del MNAC. 